\title{
Effect of photoperiod on LH, FSH, prolactin and melatonin patterns in ovariectomized prepubertal heifers*
}

\author{
J. K. Critser†, T. M. Block, S. Folkman and E. R. Hauser \\ Department of Meat and Animal Science, University of Wisconsin, Madison, WI 53706, U.S.A.
}

\begin{abstract}
Summary. Angus and Angus crossbred prepubertal heifers were ovariectomized and randomly assigned to either increasing light simulating the photoperiod of the vernal equinox to the summer solstice (I) or decreasing light simulating the photoperiod of the autumnal equinox to the winter solstice (D) for $43^{\circ} \mathrm{N}$ latitude. Three blood samples were taken each week for 14 weeks, the first at 11:00 h and two others 2 days later, $1 \mathrm{~h}$ before lights on (dark), $1 \mathrm{~h}$ before lights off (light). At the end of 14 weeks 4 heifers from each treatment group were cannulated and samples were taken for $12 \mathrm{~h}$ at 15 -min intervals, $6 \mathrm{~h}$ in the light and $6 \mathrm{~h}$ in the dark. All sera were assayed for LH, FSH and prolactin. In addition, the samples taken at 15-min intervals were assayed for melatonin. In samples taken weekly at 11:00 h circulating concentrations of $\mathrm{LH}$ and prolactin were higher among animals in Group I, while FSH concentrations were not different between Groups D and I. In samples collected weekly in the light or the dark, LH and prolactin concentrations were higher in Group I animals. However, prolactin concentrations were higher and $\mathrm{LH}$ concentrations tended to be higher in samples taken in the dark. FSH concentrations were not different between either D or I or dark and light. In samples taken at 15-min intervals the prolactin baseline was higher and pulse amplitude tended to be higher for Group I animals. Neither LH nor FSH pulse characteristics differed between I and D; however, LH baseline and LH pulse amplitude were higher in the dark. Melatonin pulse amplitude was higher among animals in Group D and higher in serum collected in the dark. These results suggest that photoperiod alters circulating concentrations of $\mathrm{LH}$ and prolactin and alters pulsatile release of $\mathrm{LH}$, prolactin and melatonin in the prepubertal heifer.
\end{abstract}

\section{Introduction}

Photoperiod serves as a phylogenetically diverse environmental regulatory cue for the control of reproduction (Farner, 1964). Mammalian species having seasonally restricted breeding seasons may be classified as long or short day breeders depending upon the duration of photoperiod that initiates reproductive function (Karsch et al., 1984). This general classification applies, by convention, to the response in the sexually mature (pubertal) animal; however, several reports indicate that the sexually immature (prepubertal) animal may respond differently, often reciprocally. The golden hamster is a long-day breeder; however, the onset of puberty is not regulated by photoperiod (Darrow et al., 1980). Wesson \& Ginther (1982) reported that long photoperiod (16 h light) delays puberty in the immature female pony, but hastens the onset of the breeding season in the mature pony. In ovary-intact sheep, short photoperiod administered constantly from birth (Yellon \& Foster, 1982) or exogenous melatonin administered 3-4 weeks after birth (Kennaway \& Gilmore,

\footnotetext{
*Reprint requests to Dr E. R. Hauser.

†Present address: Methodist Center for Reproduction and Transplantation Immunology, Methodist Hospital of Indiana, Inc., 1701 North Senate Blvd., Indianapolis, IN 46202, U.S.A.
} 
1984) delays puberty in ewe lambs, while short photoperiod (Yeates, 1949; Hart, 1950; Thwaites, 1965; Vesely, 1975) or exogenous melatonin (Nett \& Niswender, 1982; Kennaway et al., 1982) hastens the breeding season in mature, ovary-intact ewes and increases circulating concentrations of LH in ovariectomized oestradiol-treated ewes.

Cattle are not considered seasonal breeders in that oestrous cycles are continuous throughout the year even in temperate zones. However, there are times in the life of the animal when photoperiod has an influence on reproduction, most notably before puberty and after parturition (Hauser, 1984). Prepubertal heifers exposed to conditions of spring to fall (long photoperiod and increasing temperature) achieve puberty at a younger age than do those exposed to fall to spring conditions (short photoperiods and decreasing temperature) (Hawk et al., 1954; Menge et al., 1960; Roy et al., 1980; Hansen et al., 1981). Environmental conditions during the fall to spring (Critser $e t$ al., 1983) or short photoperiod (Critser et al., 1987) increase circulating concentrations of gonadotrophins in the ovariectomized oestradiol-treated mature heifer while decreasing circulating prolactin concentrations. If this reciprocal response to photoperiod between mature and immature animals is true for cattle, one would expect prepubertal ovariectomized heifers to have higher gonadotrophin concentrations when exposed to long photoperiod. The present experiment was designed to test the hypothesis (1) that increasing photoperiod increases serum LH, FSH and prolactin concentrations and (2) that photoperiod influences pulsatile characteristics of these hormones and melatonin.

\section{Materials and Methods}

\section{Experimental animals}

Nineteen Angus and Angus crossbred heifers born in March 1982 were ovariectomized before puberty at 3-7 months of age between June and October 1982. They were exposed to natural photoperiod and temperature for $43^{\circ} \mathrm{N}$ latitude until 21 March 1983.

\section{Experimental design}

At the vernal equinox, heifers were randomly assigned to one of two photoperiod treatments. Nine heifers were housed in a light controlled room equipped with fluorescent lights regulated by automatic timers and exposed to light simulating the photoperiod from the vernal equinox to the summer solstice for $43^{\circ} \mathrm{N}$ latitude. Ten heifers were housed in a similar room and exposed to light simulating the photoperiod from the autumnal equinox to the winter solstice. Photoperiod changes were made at weekly intervals. Light intensity during 'lights on' averaged 410 lux at about the height of the heifer's eyes. Several dim red lights ( $<5$ lux ) were left on at all times to facilitate sample collection after 'lights out'. At about 09:00 h each day all heifers were let out into an outside yard and at about 14:00 $\mathrm{h}$ each day they were again confined inside their respective rooms to ensure exposure to their assigned photoperiod after 'lights out'. Hay was fed ad libitum and supplemental grain was fed each day.

\section{Blood sampling}

Blood samples were withdrawn via coccygeal venepuncture three times each week for 14 weeks, from 23 March to 24 June 1983. One sample was taken at $11: 00 \mathrm{~h}$ and two others approximately 2 days later, $1 \mathrm{~h}$ before 'lights on' (dark) and $1 \mathrm{~h}$ before 'lights off' (light). At the end of the experiment, Week 15, 4 heifers from each group were fitted with indwelling jugular cannulae and samples were taken every $15 \mathrm{~min}$ from $6 \mathrm{~h}$ before to $6 \mathrm{~h}$ after lights off. Samples were taken from 14:40 to $02: 40 \mathrm{~h}$ in the light room and from 11:25 to $23: 25 \mathrm{~h}$ in the dark room. Blood was allowed to clot overnight and centrifuged; serum was decanted and stored at $-20^{\circ} \mathrm{C}$ until assayed for LH, FSH, prolactin and melatonin.

\section{Hormone assays}

The sensitivity of the assays was defined at $90 \%$ maximal binding $\left(\mathrm{B}_{0}\right)$, the intra- and interassay coefficients of variation were calculated from standard curves and quality control samples of different volumes of a serum pool from ovariectomized heifers run in quadruplicate in each assay (Baxter, 1980). All samples for all hormone determinations were assayed by duplicate and all samples from an animal were run in the same assay. An anti-rabbit gamma globulin serum fraction prepared in sheep was used as second antibody for all protein assays. 
L.H. Serum LH concentrations were determined using the RIA developed by Niswender $e t$ al. (1969). The assays were conducted using a rabbit anti-ovine antiserum (GDN No. 15) and a highly purified bovine LH preparation, ${ }^{125} \mathrm{I}-$ labelled LER-1701-2, as radioiodinated antigen. Concentrations of LH were expressed in terms of NIAMDD-bLH-4 standard. The intra-assay and interassay coefficients of variation were $5 \cdot 3 \%$ and $12 \cdot 6 \%$, respectively. Mean ( \pm s.e.m.) percentage binding was $29.7 \pm 3.5$ and the mean ( \pm s.e.m.) lower limit of sensitivity was $0.04 \pm 0.009 \mathrm{ng} / \mathrm{tube}$. Serum pools from ovariectomized heifers and from dioestrous cows produced a slope not significantly different $(P>0 \cdot 10)$ from the standard curve when run at volumes between 50 and $400 \mu \mathrm{l}$. The dioestrous cow serum pool with an added 16-fold range of standards also produced a slope not significantly different $(P>0 \cdot 10)$ from the standard curve. The recovery of this 16-fold range of standards from dioestrous serum was high $(r=0 \cdot 99, a=0 \cdot 00$ and $b=1 \cdot 12$ for a linear regression of recovered hormone against added hormone).

FSH. Serum FSH concentrations were determined using the RIA developed by Bolt \& Rollins (1983), previously validated in our laboratory (Hansen et al., 1982). The assays were conducted using rabbit antibovine FSH USDA 50122 as first antibody at a final dilution of 1:62 500. The radiolabelled antigen was a highly purified bovine FSH preparation, ${ }^{125}$ I-labelled USDA-FSH-BP3. Concentrations of FSH were expressed in terms of USDA-FSH-BP3. Serum pools from bulls and ovariectomized animals inhibited binding such that their slopes were not significantly different $(P>0.10)$ from the standard curve when assayed at volumes of 50 to $400 \mu \mathrm{l}$. The intra-assay and interassay coefficients of variation were $8 \cdot 7 \%$ and $12 \cdot 3 \%$, respectively. Mean ( \pm s.e.m.) percentage binding was $16 \cdot 8 \pm 1 \cdot 5 \%$ and mean ( \pm s.e.m.) lower limit of sensitivity was $0.49 \pm 0.052 \mathrm{ng} /$ tube.

Prolactin. Serum prolactin concentrations were determined using the RIA developed by Forrest et al. (1980) and validated in our laboratory (Schillo et al., 1983). The assays were conducted using rabbit-antiovine prolactin DJB-70330 at a final dilution of 1:1 200 000. The radiolabelled antigen was a highly purified bovine prolactin preparation, ${ }^{125}$ I-labelled USDA-bPRL-1-1. Concentrations of prolactin were expressed in terms of NIADD-Prl-B6. Serum pools from pregnant cows or ovariectomized heifers inhibited binding such that these slopes were not significantly different from the standard curve when assayed at volumes of 10 to $50 \mu$. The intra-assay and interassay coefficients of variations were $6.7 \%$ and $12.9 \%$, respectively. Mean ( \pm s.e.m.) percentage binding was $37.9 \pm 7.5 \%$ and the mean ( \pm s.e.m.) lower limit of sensitivity was $0.12 \pm 0.02 \mathrm{ng} / \mathrm{tube}$.

Melatonin. Serum melatonin ( $N$-acetyl-5-methoxytryptamine) concentrations were determined using the doubleantibody radioimmunoassay of Rollag \& Niswender (1976). Rabbit anti-melatonin (antiserum against $N$-succinyl-5methoxytryptamine-BSA conjugate) was used as first antibody at a final dilution of 1:300 000. The radiolabelled antigen was a radioiodinated melatonin-tryptamine derivative ( $N$-3,4-hydroxyphenyl-propionyl-5-methoxytryptamine). Concentrations of melatonin were expressed in terms of a crystalline melatonin preparation (Sigma Chemical Company, St Louis, MO, U.S.A.; Catalog M-5250, lot number 84C-0009).

Samples were extracted using the following procedures: 1-ml samples of serum were pipetted into extraction tubes and $\sim 4000$ c.p.m. of $\left[{ }^{3} \mathrm{H}\right]$ melatonin $\left(N\right.$-[2-aminoethyl-2- $\left.{ }^{3} \mathrm{H}\right]$-acetyl-5-methoxytryptamine, $40 \cdot 7 \mathrm{Ci} / \mathrm{mmol} ; \mathrm{New}$ England Nuclear, Boston, MA, U.S.A.) were added to each tube and incubated overnight at $4^{\circ} \mathrm{C}$. Serum was extracted with 10 volumes of chloroform (Burdick and Jackson Lab., Muskegon, MI, U.S.A.) and washed with $1 \mathrm{ml}$ $0.1 \mathrm{M}$-sodium carbonate buffer $(\mathrm{pH} 10.25)$ followed with $1 \mathrm{ml}$ deionized water. The organic phase was then taken to dryness under $\mathrm{N}_{2}$ at $40^{\circ} \mathrm{C}$ and resuspended in $1 \mathrm{ml}$ phosphate-buffered saline containing $0 \cdot 1 \%$ gelatin, pH 7.0. To determine extraction efficiency $200 \mu \mathrm{l}$ were counted in $6 \mathrm{ml}$ scintillation cocktail (Aquasol, New England Nuclear, Boston, MA, U.S.A.) and $200 \mu$ aliquants were used as sample in the assay. Mean ( \pm s.e.m.) percentage recovery was $68.9 \pm 0 \cdot 3 \%$ and the mean lower limit of sensitivity corrected for recovery was $5.2 \mathrm{pg} / \mathrm{tube}$. All samples were run in a single assay. The interassay coefficient of variation was $6.7 \%$ and binding was $38.9 \%$.

Cross-reactivity of the antiserum with $\mathrm{N}$-acetylserotonin, 5-methoxytryptophol, 6-hydroxymelatonin and 5methoxytryptamine was determined by assaying 6 logarithmic doses $\left(10^{\circ}\right.$ to $10^{6} \mathrm{pg}$ ). Relative potencies (pg melatonin/ pg compound at $50 \% \mathrm{~B}_{0}$ ) were $2.04 \times 10^{-3}, 2.01 \times 10^{-3}, 2.16 \times 10^{-3}$ and $1.60 \times 10^{-5}$, respectively. Accuracy of the assay was estimated by adding increasing concentrations of melatonin $(2.5$ to $1280 \mathrm{pg})$ to $1 \mathrm{ml}$ of a serum pool from ovariectomized heifers. These samples were extracted and run in duplicate in three separate assays. Recovery was described by linear regression and had a correlation coefficient of 0.998 , a slope of 0.978 and a $y$ intercept of $38.49 \mathrm{I}$, indicating the endogenous melatonin concentration in the serum pool. Additionally, slopes of standard curves generated from a common set of standards $(n=4)$ and of standard curves generated from a different set of standards $(n=3)$ were found not to have significantly different slopes $(P>0 \cdot 10)$.

\section{Statistical analysis}

These data acquired by repeated measurements of animals were analysed using a combination of techniques including split-plot ANOVA, Hotelling's $\mathbf{T}^{2}$-tests, polynominal contrasts and one-sided $T$-tests as previously described (Critser et al., 1987). Because of the large number of non-independent measurements taken during the frequent sampling period, the tests should be viewed as exploratory.

The 'Pulsar' program developed by Merriam \& Wachter (1982) was used in the analysis of the LH, FSH, prolactin and melatonin data from the samples taken at 15-min intervals as previously described (Critser et al., 1987). This program was designed to identify peaks by calculating a 'smoothed baseline' using a robust locally weighed regression (Cleveland, 1979), subtracting the actual hormone value from this baseline (residual), and scaling the residual using an interassay standard deviation calculated for each hormone (Baxter, 1980). The program then recalculates each of the steps excluding values designated as significant deviations from the baseline (peaks).

The number of time points over which the robust regression 'smooth baseline' was calculated was $2 \mathrm{~h}(8 \mathrm{sample}$ 
points) for $\mathrm{LH}, \mathrm{FSH}$ and melatonin and $1.5 \mathrm{~h}$ ( 6 sample points) for prolactin. The number of standard deviations a value must be above the 'baseline' to be identified as a peak was $2 \cdot 0$ standard deviations (s.d.) for a single point, 1.8 s.d. for two consecutive points and 1.6 s.d. for three consecutive points.

Four pulsatile attributes were measured for each heifer for each hormone: (1) pulse frequency (number of pulses/ $6 \mathrm{~h}$ ), (2) mean peak amplitude (maximal value of more than a single time point within a pulse, (3) mean peak duration (minutes) and (4) mean basal secretion (estimated from the robust regression).

\section{Results}

\section{Weekly samples taken at 11:00 h}

$L H$. Circulating concentrations of LH were higher $(P=0.03)$ in heifers exposed to increasing photoperiod than in those exposed to decreasing photoperiod based on comparison of the overall mean over time $(1.4 \pm 0.1$ vs $0.9 \pm 0.1 \mathrm{ng} / \mathrm{ml}$; mean \pm s.e.m.) (Fig. 1a).
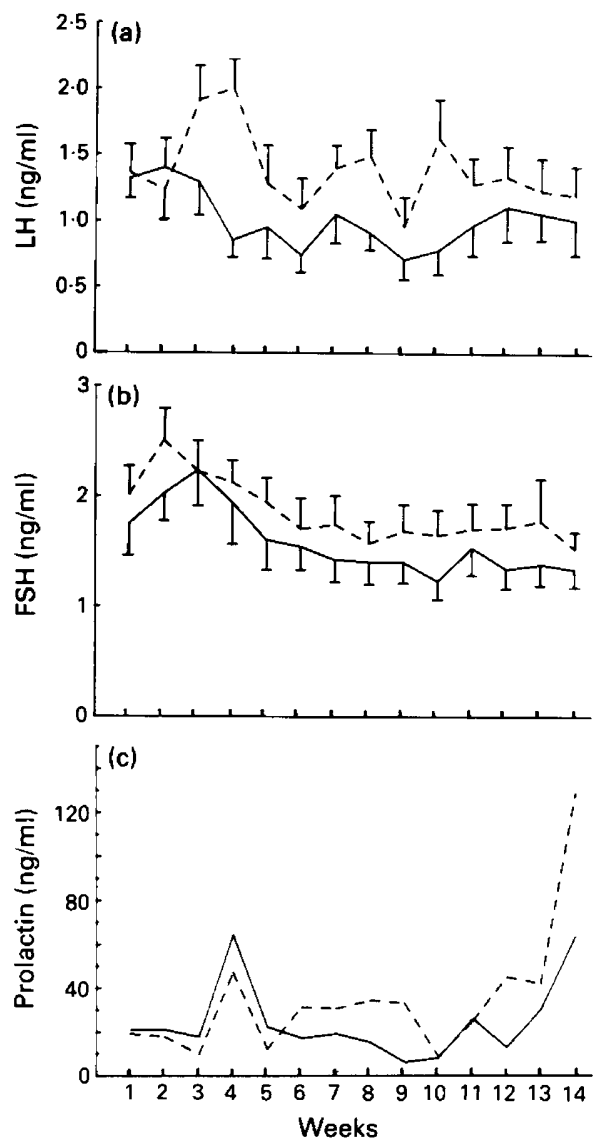

Fig. 1. Circulating concentrations of (a) LH, (b) FSH and (c) prolactin in heifers ovariectomized prepubertally and exposed to increasing $(I,--)$ or decreasing $(\mathrm{D},--)$ photoperiod. Values plotted are means \pm s.e.m. (LH and FSH) or means only (prolactin) of weekly samples taken at 11:00 $\mathrm{h}(\mathrm{I}, \mathrm{N}=9 ; \mathrm{D}, \mathrm{N}=10)$. The prolactin values are presented as means without error bars for ease of reading. The square root of the mean square error for the prolactin data is 10-67. LH concentrations: (1) were higher among animals in Group I $(P=0.03)$ and (2) decreased in both groups over time $(P=0 \cdot 01)$. FSH concentrations: $(1)$ were not different between Groups I and D, but (2) decreased in both groups over time $(P=0 \cdot 01)$. Prolactin concentrations were higher in Group I $(P=0.04)$ and there was a photoperiod by time interaction $(P=0 \cdot 01)$. 


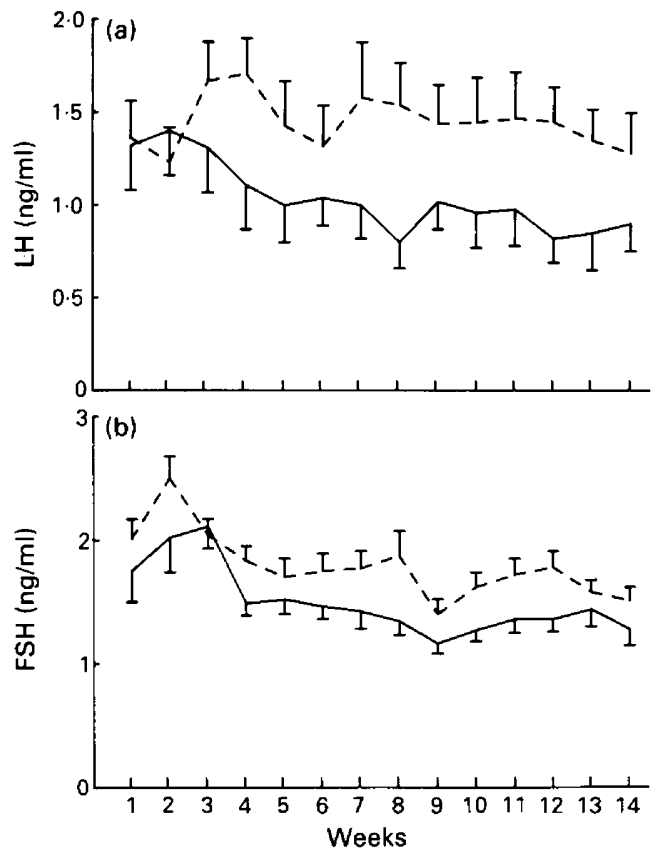

Fig. 2. Circulating concentrations of (a) LH and (b) FSH in heifers ovariectomized prepubertally and exposed to increasing $(\mathrm{I},---)$ or decreasing $(\mathrm{D},-\longrightarrow)$ photoperiod. Values plotted are means \pm s.e.m. of weekly samples taken $1 \mathrm{~h}$ before lights on and $1 \mathrm{~h}$ before lights off. LH concentrations were higher in Group I $(P=0.01)$. There was a tendency $(P=0.12)$ for concentrations to be higher in the dark. FSH concentrations did not differ between Groups I and D $(P=0.19$ but did decrease over time $(P=0.01)$.

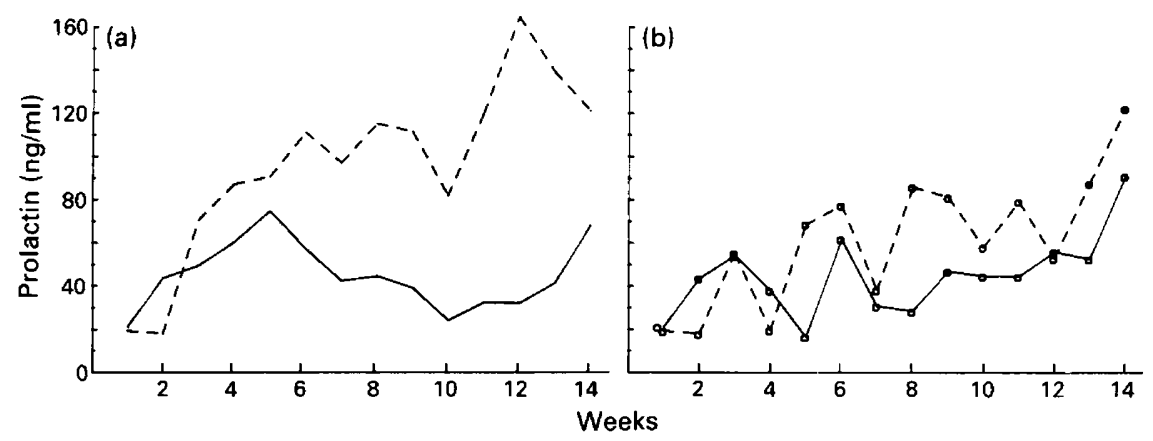

Fig. 3. Circulating concentrations of prolactin in heifers ovariectomized prepubertally. Values plotted are means of weekly samples taken (a) $1 \mathrm{~h}$ before lights on and (b) $1 \mathrm{~h}$ before lights off $\left(\mathrm{I},---; \mathrm{D},-{ }_{-}\right.$). The square roots of the mean square errors for testing differences between Groups I and D and light and dark are 12.37 and 13.18, respectively. Prolactin concentrations were higher in Group I $(P=0.001)$ and in the dark $(P=0.001)$. There were significant photoperiod $\times$ time $(P=0.001)$, photoperiod $\times$ light/dark $(P=0.001)$ and photoperiod $\times$ light/ dark $\times$ time $(P=0.001)$ interactions. 


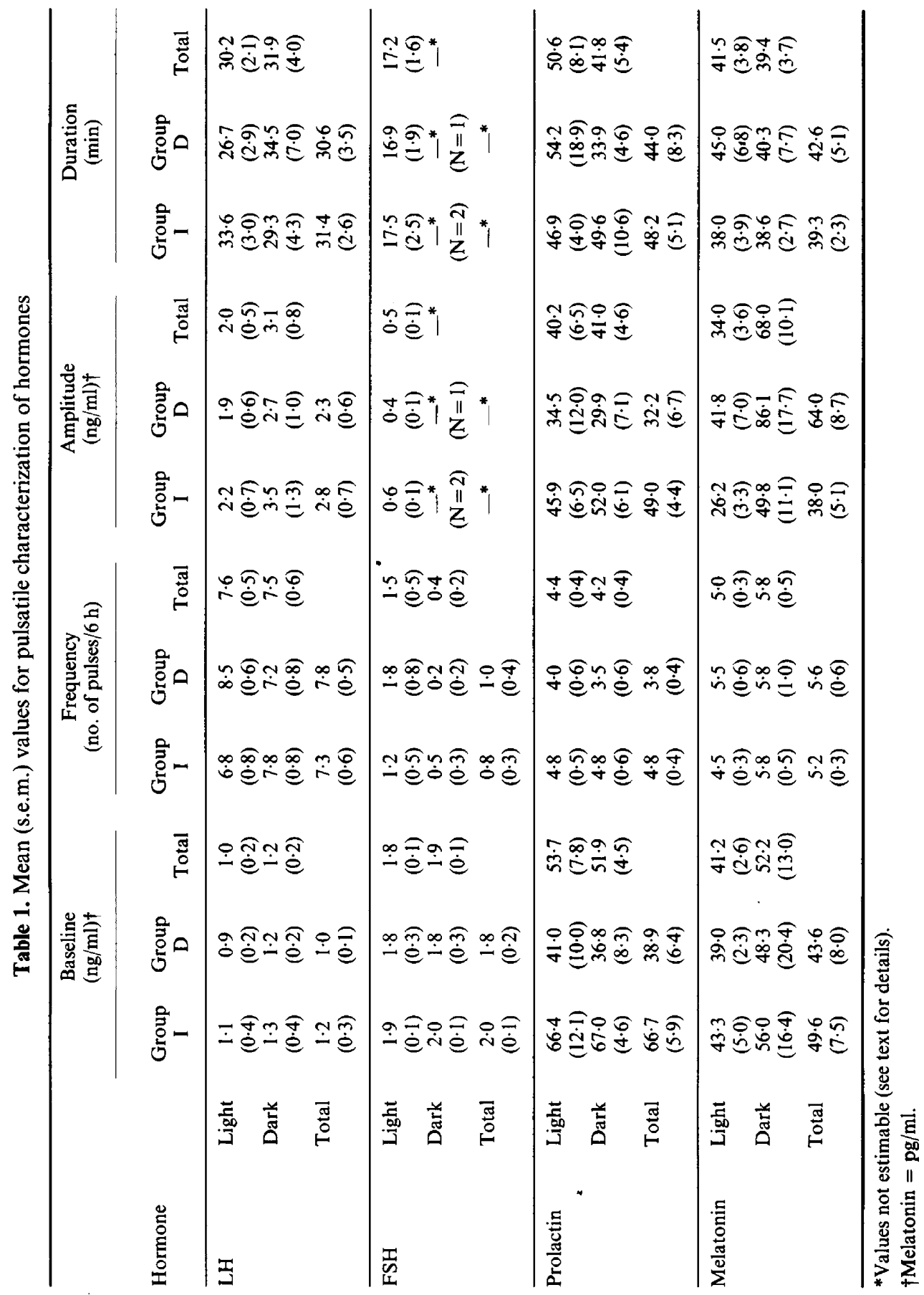


FSH. Serum concentrations of FSH were not different between heifers exposed to increasing or decreasing photoperiod $(1.8 \pm 0.1$ vs $1.5 \pm 0.1 \mathrm{ng} / \mathrm{ml})$ (Fig. $1 \mathrm{~b})$.

Prolactin. Circulating concentrations of prolactin were higher $(P=0.04)$ in heifers exposed to increasing photoperiod than in those exposed to decreasing photoperiod $(37.3 \pm 3.6 \mathrm{vs}$ $25 \cdot 3 \pm 2 \cdot 6 \mathrm{ng} / \mathrm{ml}$ ) (Fig. 1c).

\section{Light and dark samples}

$L H$. When samples were taken in the light (l) or dark (d), LH tended to be higher $(P=0 \cdot 12$; data not shown) in the dark than in light $(1.3 \pm 0.04$ vs $1.2 \pm 0.04 \mathrm{ng} / \mathrm{ml})$. In addition these samples show patterns similar to those taken at 11:00 h in that $\mathrm{LH}$ concentrations were higher $(P=0.008)$ in animals exposed to increasing photoperiod (Il and Id) than those exposed to decreasing photoperiod (Dl and Dd) $(1.5 \pm 0.04 v s 1.0 \pm 0.04 \mathrm{ng} / \mathrm{ml})($ Fig. 2a).

$F S H$. Concentrations $(\mathrm{ng} / \mathrm{ml})$ did not differ $(P=0.27$; data not shown) between dark and light samples $(1.5 \pm 0.04$ vs 1.6 \pm 0.04$)$. Similar to samples taken at 11:00 h, FSH concentrations were not different $(P=0 \cdot 19)$ in animals exposed to increasing (Il and Id) or decreasing (Dl and Dd) photoperiod $(1 \cdot 8 \pm 0.04$ vs $1 \cdot 5 \pm 0.04)$ (Fig. $2 \mathrm{~b}$ ).

Prolactin. Serum concentrations of prolactin were higher $(P=0 \cdot 01)$ in samples taken in the dark than in light $(76.4 \pm 3.6 \mathrm{vs} 52.8 \pm 2.5 \mathrm{ng} / \mathrm{ml})$ (Fig. 3). In addition, similar to the samples taken at 11:00 h, prolactin concentrations were higher $(P=0.002)$ in heifers exposed to increasing photoperiod (Il and Id) and those exposed to decreasing photoperiod (Dl and Dd) (83.5 $\pm 3.7 \mathrm{vs}$ $46 \cdot 0 \pm 2 \cdot 0 \mathrm{ng} / \mathrm{ml}$ ) (Fig. 3).

(a) Decreasing
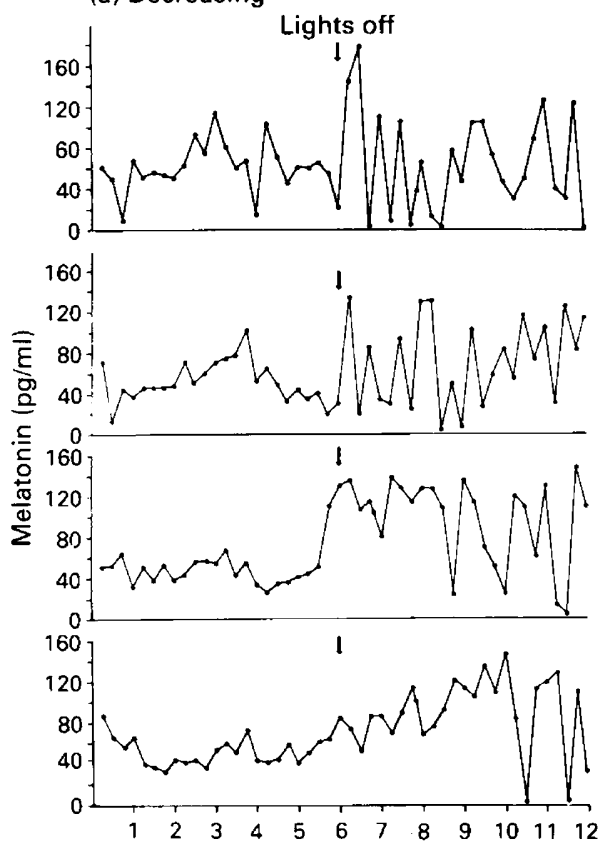

(b) Increasing
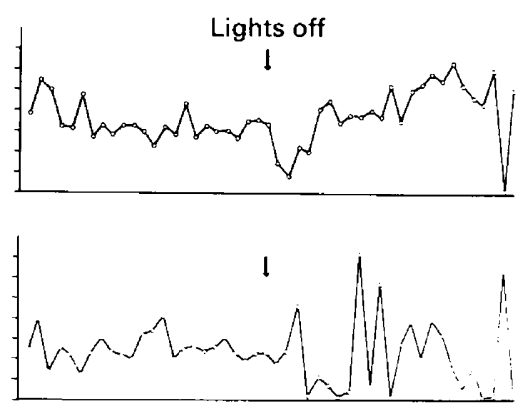

l

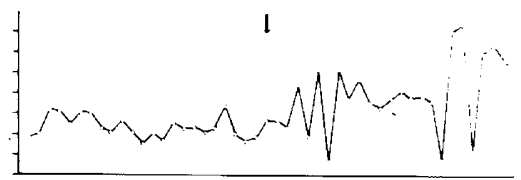

1

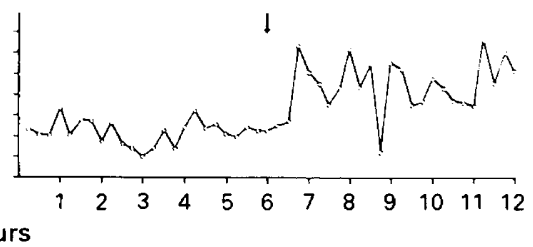

Fig. 4. Circulating concentrations of melatonin in heifers ovariectomized prepubertally and exposed to (a) decreasing (D, - $)$ ) or (b) increasing $(\mathrm{I}, \mathrm{O}-\mathrm{O}$ ) photoperiod. Values plotted are individual observations for an animal. Melatonin was found to have a marked pulsatile secretory pattern in both photoperiod treatments. Neither baseline nor pulse frequency differed between groups $(P=0.64 ; P=0.41)$; however, pulse amplitude was higher $(P=0.05)$ in animals exposed to decreasing photoperiod. 


\section{Frequent samples}

$L H$. Baseline $\mathrm{LH}$, pulse frequency and pulse amplitude were not different between increasing (Il and Id) or decreasing (Dl and Dd) photoperiod treatments; but baseline and pulse amplitude were higher $(P=0.01)$ in samples taken during the dark (Id and Dd) than in the light (Il and Dl) $(1.2 \pm 0.3$ vs $1.0 \pm 0.2 \mathrm{ng} / \mathrm{ml}$ and $3.1 \pm 0.8 v s 2.0 \pm 0.5 \mathrm{ng} / \mathrm{ml})($ Table 1$)$

$F S H$. Pulses of FSH generally occurred at frequencies of less than 1 per $6 \mathrm{~h}$ in the dark. Therefore, the end points of pulse amplitude and duration were not measurable. Baseline concentrations of FSH were not different between animals receiving increasing (Il and Id) or decreasing photoperiod (Dl and Dd) $(P=0.73 ; 1.8 \pm 0.2$ vs $2.0 \pm 0.1 \mathrm{ng} / \mathrm{ml}$ or between animals in light (Il and Dl) or dark (Id and Dd) $(P=0.77 ; 1.8 \pm 0.1$ vs $1.9 \pm 0.1 \mathrm{ng} / \mathrm{ml})$. However, FSH pulse frequency was higher $(P=0.09)$ in the light (Il and D1) $(1.5 \pm 0.5 v s 0.4 \pm 0.2$ pulses $/ 6 \mathrm{~h})$ than in the dark (Id and Dd) (Table 1).

Prolactin. Baseline concentrations of prolactin were higher $(P=0.07)$ and prolactin pulse amplitude tended to be higher $(P=0 \cdot 14)$ in animals receiving increasing photoperiod (Il and Id; $66.7 \pm 5.9 \mathrm{ng} / \mathrm{ml}$ and $49.0 \pm 4.4 \mathrm{ng} / \mathrm{ml}$ ) than in animals receiving decreasing photoperiod (Dl and Dd; $38.9 \pm 6.4 \mathrm{ng} / \mathrm{ml}$ and $32 \cdot 2 \pm 6.7 \mathrm{ng} / \mathrm{ml}$ ) (Table 1$)$. There was a treatment $\times$ light/dark interaction $(P=0.02)$ for prolactin pulse amplitude with the amplitude lower for Group I heifers in the dark and pulse amplitude higher for those in Group D in the dark (Table 1).

Melatonin. Melatonin had a pulsatile secretory pattern in both treatments (Fig. 4). Neither baseline nor pulse frequency differed between Groups I (Il and Id) and D (Dl and Dd) $(P=0 \cdot 64$; $P=0.41)$; however, pulse amplitude was higher $(P=0.05)$ in animals exposed to decreasing photoperiod ( $\mathrm{Dl}$ and $\mathrm{Dd}$ ) than in those exposed to increasing photoperiod (Il and Id) $(64.0 \pm 8.7 \mathrm{vs}$ $38.0 \pm 5 \cdot 1 \mathrm{pg} / \mathrm{ml}$ ) and higher for all samples taken in the dark (Id and Dd) than in the light (Il and Dl) $(P=0 \cdot 01 ; 68 \cdot 0 \pm 10 \cdot 1$ vs $34.0 \pm 3.6 \mathrm{pg} / \mathrm{ml}$ (Table 1$)$.

\section{Discussion}

Serum LH and prolactin concentrations were greater in prepubertal heifers receiving increasing photoperiod. Serum FSH concentrations were not different due to photoperiod change. These results suggest that photoperiod alters circulating concentrations of $\mathbf{L H}$ and prolactin in the prepubertal heifer. Tucker (1982) has reported positive effects of increasing photoperiod on prolactin concentrations in the prepubertal and pubertal heifer. However, the positive effect of photoperiod on LH has not previously been demonstrated and suggests a regulatory mechanism for observations that puberty is hastened in heifers born in spring and therefore exposed to environmental conditions of increasing photoperiod and temperature (Hawk et al., 1954; Menge et al., 1960; Roy et al., 1980), or by long photoperiod alone (Hansen et al., 1981).

Pubertal ovariectomized heifers with or without replacement oestradiol treatment have low concentrations of LH in summer and high concentrations of LH in winter (Critser et al., 1983). In addition, pubertal ovariectomized heifers with replacement oestradiol have lower concentrations of gonadotrophins when exposed to long photoperiod and higher concentrations of gonadotrophins when exposed to short photoperiod (Critser et al., 1987).

These observations suggest a reciprocal reproductive response to photoperiod expressed by immature and mature heifers. This kind of reciprocal reproductive response between age and photoperiod has been observed in other species. Wesson \& Ginther (1982) reported that long photoperiod ( $16 \mathrm{~h}$ light) delays puberty in the immature female pony but hastens the onset of the breeding season in the mature pony. In sheep short photoperiod administered constantly from birth (Yellon \& Foster, 1982) or exogenous melatonin administered 3-4 weeks after birth (Kennaway \& Gilmore, 1984) delays puberty in ewe lambs, while short photoperiod (Yeates, 1949; Hart, 1950; Thwaites, 1965; Vesely, 1975) or exogenous melatonin (Nett \& Niswender, 1982; Kennaway et al., 1982) hastens the breeding season in mature ewes. 
These observations may indicate a common phenomenon in reproductive biology, that animals respond differently to the influence of photoperiod at various stages of their reproductive lives. This interaction between age and photoperiod in reproductive development may involve a change in response of the immature and mature hypothalamo-hypophysial axis to melatonin.

Pulsatile patterns of LH, FSH and prolactin were observed as previously reported (Forrest $e t$ al., 1980; Rahe et al., 1980; Walters \& Schallenberger, 1984; Walters et al., 1984; Critser et al., 1987). Higher concentrations of prolactin in Group I heifers sampled weekly were associated with higher prolactin pulse frequency. This is consistent with findings that pubertal heifers have higher weekly prolactin values and prolactin pulse frequencies (Critser et al., 1987). Higher LH concentrations in Group I were not associated with a change in any of the pulsatile characteristics. This differs from pubertal heifers in that higher LH concentrations were associated with both increased baseline and pulse amplitude (Critser et al., 1987). Schillo et al. (1983) reported differences in the pulsatile secretory patterns in prepubertal and pubertal heifers, indicating that photoperiod may control the ontogeny of the gonadotrophin 'pulse generator'.

Melatonin concentrations were higher in heifers receiving decreasing photoperiod and in all animals when samples were taken in the dark. Elevated serum concentrations of melatonin in the dark are consistent with previous reports for cattle (Helund et al., 1977; Martin et al., 1983) and sheep (Rollag \& Niswender, 1976). Rollag \& Niswender (1976) found circulatory concentrations of melatonin in sheep to be $10-30 \mathrm{pg} / \mathrm{ml}$ during periods of light and $100-300 \mathrm{pg} / \mathrm{ml}$ during periods of dark. Using the same assay, Hedlund et al. (1977) found plasma levels of melatonin in calves to be $\sim 20 \mathrm{pg} / \mathrm{ml}$ in the light and $\sim 120 \mathrm{pg} / \mathrm{ml}$ in the dark. In the current study, samples taken in the light contained $40-60 \mathrm{pg}$ melatonin $/ \mathrm{ml}$ while those taken in the dark were $80-120 \mathrm{pg} / \mathrm{ml}$. We have no explanation why the present results show a smaller difference in melatonin concentrations between daytime and nighttime values (2-3-fold rather than 6-10-fold). Arendt et al. (1981) have reported significant variation in the magnitude of nighttime melatonin amongst individual ewes, and it may be that the individual heifers used in this experiment were, on average, low responders. Alternatively, the dim red light used to aid in the collection of nighttime samples may have 'dampened' the nocturnal melatonin rise, although the use of red light is common to many studies with sheep (e.g. Bittman et al., 1983) and to the best of our knowledge dampening effects have not been previously suggested.

In addition, the current study found melatonin to be secreted episodically. Episodic release of melatonin has been reported for horses (Sharp \& Grubaugh, 1983) and sheep (Bittman et al., 1983) but pulsatile patterns have not been previously reported for the cow. Differentiation of baseline values versus pulsatile values of melatonin revealed that it was not melatonin baseline which differed between treatment group (I versus D) or between the light and dark sampling times. Rather, melatonin pulse amplitude was higher in the decreasing photoperiod group and in samples taken in the dark. This observation of pulsatile secretion and the observation that pulse amplitude varies with daylength and scotophase and photophase may be important to further elucidation of the mechanisms of action for this hormone and its influence on gonadotrophin concentrations. Although constant infusions of melatonin in sheep produce physiological effects on reproduction (Karsch et al., 1984), the observation that melatonin is secreted in a pulsatile manner may be of importance to experiments in which exogenous melatonin is administered, as the pattern of administration has been shown to alter the response to other hypophysiotrophic hormones such as GnRH (Blake et al., 1980).

We thank Dr G. D. Niswender for the LH and melatonin antisera; Dr W. Schramm for the melatonin derivative for iodination; Dr L. Reichert for providing the LH used for iodination; $\mathrm{Dr}$ D. J. Bolt and the USDA for donation of FSH and prolactin standard and antisera; the National Institute of Arthritis, Metabolism and Digestive Diseases for LH standards; and Julie Busby for preparation of the manuscript. 


\section{References}

Arendt, J., Symons, A.M. \& Laud, C. (1981) Pineal function in the sheep: evidence for a possible mechanism mediating seasonal reproductive activity. Experientia 37, 584-586.

Baxter, R.C. (1980) Simplified approach to confidence limits in radioimmunoassay. Clin. Chem. 26, 763-765.

Bittman, E.L., Dempsey, R.J. \& Karsch, F.J. (1983) Pineal melatonin secretion drives the reproductive response to day length in the ewe. Endocrinology 113, $2267-2283$

Blake, C.A., Siraran, R., Elias, K.A., Ashiru, O.H. \& Rush, M.E. (1980) Plasma LH patterns after LHRH infusion in long term unanesthetized ovariectomized rats. Neuroendocrinology 30,45-51.

Bolt, D.J. \& Rollins, R. (1983) Development and application of a radioimmunoassay for bovine folliclestimulating hormones. J. Anim. Sci. 56, 146-154.

Cleveland, W.S. (1979) Robust locally weighted regression and smoothing scatterplots. J. Am. Stat. Assoc. 74, 829-836.

Critser, J.K., Miller, K.F., Gunsett, F.C. \& Ginther, O.J. (1983) Seasonal LH profile in ovariectomized cattle. Theriogenology 19, 181-191.

Critser, J.K., Lindstrom, M.J., Hinshelwood, M.M. \& Hauser, E.R. (1987) Effect of photoperiod on LH, FSH and prolactin patterns in ovariectomized oestradiol-treated heifers. J. Reprod. Fert. 79, 599-608.

Darrow, J.M., Davis, F.C., Elliott, J.A., Stetson, M.H., Turek, F.W. \& Menaker, M. (1980) Influence of photoperiod on reproductive development in the golden hamster. Biol. Reprod. 22, 433-450.

Farner, D.S. (1964) Comparative physiology: photoperiodicity. Am. Rev. Physiol. 23, 71-96.

Forrest, D.W., Fleeger, J.L., Long, C.R., Sorenson, A.M. \& Harmes, P.G. (1980) Effect of exogenous prolactin on peripheral luteinizing hormone levels in ovariectomized cows. Biol. Reprod. 22, 197-201.

Hansen, P.J., Schillo, K.K., Kamwanja, L.A., Hauser, E.R. \& Dierschke, D.J. (1981) The influence of season on sexual development in the bovine female: ovarian growth and body weight as related to puberty. In Dynamics of Ovarian Function, pp. 239-244. Eds N. B. Schwartz \& M. Hunzicker-Dunn. Raven Press, New York.

Hansen, P.J., Kamwanja, L.A. \& Hauser, E.R. (1982) The effect of photoperiod on serum concentrations of luteinizing and follicle stimulating hormones in prepubertal heifers following ovariectomy and estradiol injection. Theriogenology 18, 551-559.

Hart, D.S. (1950) Photoperiodicity in Suffolk sheep. $J$. agric. Sci., Camb. 40, 143-149.

Hauser, E.R. (1984) Seasonal effects on female reproduction in the bovine (Bos taurus) (European breeds). Theriogenology 21, 150-170.

Hawk, H.W., Tyler, W.J. \& Casida, L.E. (1954) Some factors affecting age at puberty in Holstein-Friesian heifers. J. Dairy Sci. 37, 252.

Hedlund, L., Lischko, M.M., Rollag, M.D. \& Niswender, G.D. (1977) Melatonin: daily cycle in plasma and cerebrospinal fluid of calves. Science, N.Y. 195, 686-687.
Karsch, F.J., Bittman, E.L., Foster, D.L., Goodman, R.L., Legan, S.J. \& Robinson, J.E. (1984) Neuroendocrine basis of seasonal reproduction. Recent Prog. Horm. Res. 40, 185-232.

Kennaway, D.J. \& Gilmore, T.A. (1984) Effects of melatonin implants in ewe lambs. J. Reprod. Fert. 70, 39-45.

Kennaway, D.J., Gilmore, T.A. \& Seamark, R.F. (1982) Effect of melatonin feeding on serum prolactin and gonadotropin levels and the onset of seasonal estrous cyclicity in sheep. Endocrinology 110, 1766-1772.

Martin, T.C., Cunningham, N.F. \& Saba, N. (1983) Estimation of melatonin in bovine plasma: patterns of Jersey heifers treated with cloprostenol at two times of the day. J. Endocr. 98, 189-196.

Menge, A.C., Mares, S.E., Tyler, W.J. \& Casida, L.E. (1960) Some factors affecting age at puberty and the first 90 days of lactation in Holstein heifers. $J$. Dairy Sci. 43, 1099-1107.

Merriam, G.R. \& Wachter, K.W. (1982) Algorithms for the study of episodic hormone secretion. Am. J. Physiol. 243, E310-E318.

Nett, T.M. \& Niswender, G.D. (1982) Influence of exogenous melatonin on seasonality of reproduction in sheep. Theriogenology 17, 645-653.

Niswender, G.D., Reichert, L.E., Jr, Midgley, A.R., Jr \& Nalbandov, A.V. (1969) Radioimmunoassay for bovine and ovine luteinizing hormone. Endocrinology 84, $1166-1173$.

Rahe, C.H., Owens, R.E., Fleeger, J.L., Newton, H.J. \& Harms, P.G. (1980) Patterns in plasma luteinizing hormone in the cyclic cow: dependence upon the period of the cycle. Endocrinology 107, 489-503.

Rollag, M.D. \& Niswender, G.D. (1976) Radioimmunoassay of serum concentrations of melatonin in sheep exposed to different lighting regimens. Endocrinology 98, 482-489.

Roy, J.H.B., Gillies, C.M., Perfitt, M.W. \& Stobo, I.J.F. (1980) The effect of season of the year and phase of the moon on puberty and on the occurrence of oestrus and conception of dairy heifers reared on high planes of nutrition. Anim. Prod. 31, 13-36.

Schillo, K.K., Dierschke, D.J. \& Hauser, E.R. (1983) Estrogen induced release of luteinizing hormone in prepubertal and postpubertal heifers. Theriogenology 19, 727-738.

Sharp, D.C. \& Grubaugh, W.R. (1983) Pulsatile secretion of melatonin during the scotophase in mares. Biol. Reprod. 28 (Suppl. 1), 100, Abstr.

Thwaites, C.J. (1965) Photoperiodic control of breeding activity in the Southdown ewe with particular reference to the effects of an equatorial light response. $J$. agric. Sci., Camb. 65, 57-64.

Tucker, H.A. (1982) Seasonality in cattle. Theriogenology 17, 53-59.

Vesely, J.A. (1975) Induction of lambing every eight months in two breeds of sheep by light control with or without hormonal treatment. Anim. Prod. 21, $165-174$.

Walters, D.L. \& Schallenberger, E. (1984) Pulsatile secretion of gonadotrophins, ovarian steroids and ovarian oxytocin during the periovulatory phase of 
the oestrous cycle in the cow. J. Reprod. Fert. 71, Yeates, N.T.M. (1949) The breeding season of the sheep $503-512$.

Walters, D.L., Shams, D. \& Schallenberger, F. (1984) Pulsatile secretion of gonadotrophins, ovarian steroids and ovarian oxytocin during the luteal phase of the oestrous cycle in the cow. J. Reprod. Fert. 72, 479-491.

Wesson, J.A. \& Ginther, O.J. (1982) Influence of photoperiod on puberty in the female pony. J. Reprod. Fert., Suppl. 32, 269-274. with particular reference to its modification by artificial means using light. J. agric. Sci., Camb. 39, 1-73. Yellon, S.M. \& Foster, D.L. (1982) Long days are required to initiate and sustain ovulatory cycles under short days in the lamb. Biol. Reprod. 26 (Suppl. 2), 125A, Abstr.

Received 24 November 1986 